\title{
INDIKATOR PENGEMBANGAN KARAKTER SISWA SEKOLAH DASAR
}

\section{Bayu Purbha Sakti}

\begin{abstract}
Abstrak : Beberapa masalah yang telah terjadi di sekolah dasar seperti kekerasan anak, siswa tidak lulus, dan siswa drop out. Beberapa masalah tersebut telah menyebabkan berbagai pendapat yang memprihatinkan. Indikator dalam pendidikan diperlukan oleh pendidik demi pengembangan karakter siswa sekolah dasar. Pendidikan dan penilaian karakter yang diadakan di sekolah dasar digunakan untuk pengembangan karakter. Pengembangan karakter dilakukan untuk mengembangkan karakter siswa sekolah dasar sesuai karakter yang baik. Ruang lingkup pendidikan karakter selain di sekolah adalah di keluarga, masyarakat, instansi pemerintah maupun swasta, serta ruang lingkup di luar negeri. Penanaman nilai karakter dapat dilakukan dalam kegiatan pembelajaran. Teknik penilaian karakter yang digunakan di sekolah dasar meliputi: observasi, wawancara, catatan anekdot, dan catatan kejadian tertentu. Pengembangan karakter dapat dilakukan dengan memasukkan konsep karakter pada setiap pembelajaran di sekolah dasar. Beberapa pengembangan karakter itu antara lain: Guru menanamkan nilai kebaikan pada anak dengan menanamkan konsep diri yang baik kepada anak setiap akan memasuki pelajaran. Guru menggunakan cara yang membuat anak memiliki alasan atau keinginan untuk berbuat baik. Guru memberikan beberapa contoh baik kepada anak mengenai karakter yang sedang dibangun. Guru mengembangkan sikap mencintai perbuatan baik. Guru melaksanakan perbuatan baik.
\end{abstract}

Kata Kunci : penilaian karakter, sekolah dasar, observasi, guru

\section{PENDAHULUAN}

Berbagai masalah yang terjadi pada pelaksanaan pendidikan di sekolah dasar telah menyebabkan pemberitaan di berbagai media. Kasus kekerasan merupakan salah satu masalah kasus karakter di sekolah dasar. Kasus kekerasan anak yang terjadi di Bukittinggi sudah menjadi perbincangan yang ramai di Website dari Youtube. Di situs tersebut, siswa sekolah dasar menyiksa temannya sendiri dan peristiwa itu terjadi di SD Trisula Bukit Tinggi (https:/ /www.youtube.com/watch?v=BabV7fjfJyI). Video itu menayangkan sejumlah murid laki-laki memukuli dan menendang teman perempuannya beredar di jejaring sosial.
Dalam video kekerasan yang terjadi di SD Trisula Bukit Tinggi, seorang siswi di pojok ruangan dihujani pukulan dan tendangan oleh sekitar dua siswa dan satu siswi. "Ibu saya dihina oleh teman ini. Ibu saya disamakan dengan sepatu," kata siswa pelaku pemukulan itu (Sudiaman, 2014). Saat anak-anak siswa SD tersebut diminta keterangan, mereka mengaku hanya iseng melakukan pemukulan. Setelah mereka didesak, barulah anak-anak bercerita. Menurut salah seorang anak yang melakukan pemukulan itu, ia memukul atas dasar sakit hati kepada siswi berkerudung yang ia pukuli.

\footnotetext{
* Progdi PGSD, FKIP, Unwidha
} 
Berkaitan dengan masalah di sekolah dasar maka terdapat data pendidikan Kementrian Pendidikan dan Kebudayaan tahun 2015/2016 yang menunjukkan bahwa terdapat 946.013 siswa lulus SD yang tidak melanjutkan ke SMP. Jumlah siswa SD melanjutkan ke SMP tetapi tidak lulus sebanyak 51.541 siswa sehingga ada 997.554 anak Indonesia yang hanya berstatus tamatan SD pada 2015/2016. Jumlah orang Indonesia yang hanya memegang ijazah SD akan terus meningkat jika hal itu terus terjadi setiap tahun. Hal itu berarti bahwa masalah pendidikan sekolah dasar akan terus bertambah. Masalah karakter yang dimiliki seorang lulusan SD akan menjadi perbincangan di waktu dewasa orang tersebut.

Wakil Ketua Komisi X DPR RI Sutan Adil Hendra prihatin dengan tingginya angka putus sekolah dikalangan siswa Sekolah Dasar (SD), yang menurutnya jumlahnya mencapai 500 ribu lebih dari total 31 juta siswa SD di Indonesia (Pasaribu, 2016). Angka tersebut secara presentase memang kecil namun jumlahnya cukup besar yakni 500 ribu siswa SD putus sekolah tiap tahun. Ada 5 juta anak kita yang akan kehilangan potensi masa depan dalam satu dasawarsa karena putus sekolah jika tidak ada solusi dan perbaikan dalam pendidikan di Indonesia. Hal tersebut akan menjadi masalah yang berat bagi bangsa Indonesia karena lulusan SD akan bekerja menjadi apa dan hal itu akan mempengaruhi kebutuhan ekonominya. Hal tersebut juga akan menjadi karakter bangsa dimana bangsa tersebut memiliki beberapa karakter rakyat yang hanya menjadi lulusan SD.

Banyak sekolah yang kekurangan siswa di Kabupaten Gresik, terutama sekolah tingkat dasar atau SD (Taufik, 2016). Sekolah-sekolah yang memiliki kekurangan siswa itu mencapai 147 sekolahan dan beberapa sekolah itu tersebar di sejumlah wilayah di Gresik. Dinas Pendidikan Kabupaten Gresik mengaku telah melakukan kajian untuk memastikan sekolah yang bisa digabung dan mana yang tidak. Guru Pegawai Negeri Sipil (PNS) di sekolah yang kekurangan murid itu tidak akan memperoleh tunjangan profesi sebagaimana ketentuan dalam Peraturan Pemerintah nomer 74 tahun 2008 jika tidak ada penggabungan sekolah. Berdasarkan Peraturan Pemerintah nomer 74 tahun 2008 dijelaskan bahwa jumlah siswa sekolah dasar adalah 120 siswa. Masalah penggabungan sekolah dilakukan supaya tidak terdapat beberapa siswa yang drop out. Siswa yang drop out akan menyebabkan masalah lagi bagi pendidikan sekolah dasar terutama berkaitan dengan masalah karakter siswa.

Masalah siswa sekolah dasar yang drop out akan menjadi tanggung jawab siswa itu sendiri nantinya di kehidupan dewasanya. Tanggung jawab yang merupakan bagian dari nilai karakter tentunya saja harus dilaksanakan oleh setiap Warga Negara Indonesia. Program Wajib Belajar 9 Tahun harus menuntut setiap Warga Negara Indonesia untuk melaksanakan pendidikan di tingkat sekolah dasar dan sekolah menengah pertama. Hal itu tentunya menjadi tanggung jawab setiap siswa di sekolah dasar. Jika terdapat lulusan siswa sekolah dasar yang tidak melanjutkan pendidikan ke jenjang sekolah menengah pertama maka tanggung jawabnya pun dipertanyakan.

Berdasarkan penelitian yang dirilis UNDP (United Nations Davelopment Programme), tingkat pendidikan di Indonesia hanya 14.6\%; jauh lebih rendah dibandingkan dengan Malaysia yang mencapai 28\% dan Singapura 33\%. Suatu hal untuk meningkatkan daya saing di bidang pendidikan adalah dengan menambah pengetahuan lewat aktivitas membaca. Meningkatkan minat baca ini harus dimulai dari masa kanak-kanak sampai masa sekolah dasar. Oleh karena 
itu, budaya membaca jika dilaksanakan akan menjadi budaya dan karakter siswa sekolah dasar.

Di tahun 2016, Majalah Bobo menunjuk Yayasan 1001 Buku sebagai penyedia materi dan pelaksana kegiatan Konferensi Anak Indonesia di Jakarta (Suhartadi, 2016). Konferensi Anak Indonesia diikuti oleh 36 siswa sekolah dasar dari seluruh Indonesia yang mengikuti Konferensi ini. Mereka terpilih dari 1800 anak sekolah dasar yang mengikuti seleksi pemilihan delegasi dengan mengirimkan karya tulisnya ke panitia pemilihan. Konferensi Anak Indonesia diadakan untuk mendorong anak-anak Indonesia berlatih mandiri, berfikir kritis, dan peduli terhadap masalah-masalah yang terjadi di lingkungan sekitar terutama masalah karakter.

Pendidikan karakter harus mendominasi pendidikan dasar, untuk tingkat SD pendidikan karakter dan budi pekerti itu proporsinya 70 persen dan untuk tingkat SMP sebanyak 60 persen (Effendi, 2016). Mendikbud menyampaikan beberapa hal yang berkaitan tentang masalah pendidikan di sekolah dasar saat beliau membuka Pekan Olahraga dan Seni (Porseni) PGRI di Siak, Riau. Pendidikan karakter itu mutlak diberikan oleh para guru untuk tingkat pendidikan dasar. Ada tiga aspek penting yang menentukan pelaksanaan pendidikan karakter yakni etika, estetika dan kinestetika. Semua hak itu diajarkan oleh guru mulai dari guru budi pekerti, guru seni dan olahraga. Guru berhak menentukan dan menerjemahkan pendidikan karakter tersebut. Oleh karena itu peran guru sangatlah penting dalam pembangunan dan pengembangan pendidikan karakter.

Berdasarkan beberapa masalah yang telah terjadi. Peran pengembangan dan pembangunan karakter siswa sekolah dasar menjadi suatu hal yang sangat penting untuk dilaksanakan di sekolah dasar.
Oleh karena itu, hal ini perlu dibahas untuk mendapatkan solusi dalam membangun karakter siswa sekolah dasar. Sekolah dasar yang memiliki pengembangan karakter yang lebih baik terhadap anak sangat dibutuhkan untuk mendidik anak supaya anak memperoleh pendidikan karakter. Pendidikan karakter inilah yang akan membangun karakter siswa sekolah dasar menjadi cikal bakal warga negara yang berguna bagi bangsa. Oleh karena itu, indikator dalam pendidikan diperlukan oleh pendidik dalam melaksanakan kegiatan pembelajaran demi pembangunan dan pengembangan karakter siswa sekolah dasar.

\section{RUMUSAN MASALAH}

Berdasarkan keterangan yang dijelaskan pada bagian pendahuluan di atas, maka terdapat permasalahan yang dipertanyakan yaitu bagaimana indikator pengembangan karakter siswa sekolah dasar?

\section{PEMBAHASAN}

Beberapa masalah yang perlu dibahas berdasarkan pertanyaan dari permasalahan adalah definisi pendidikan karakter, penilaian karakter, dan pengembangan karakter terhadap siswa sekolah dasar. definisi pendidikan karakter dibahas untuk mengetahui penjelasan- penjelasan yang berkaitan pendidikan karakter. Penilaian karakter dibahas untuk mengetahui nilai-nilai dari karakter dan penilaiannya yang digunakan di sekolah dasar. Pengembangan karakter dibahas untuk mengetahui cara dan langkah-langkah yang harus dilakukan dalam mengembangkan karakter siswa sekolah dasar (elementary school student character) sesuai karakter yang baik (good character). 


\section{Definisi Pendidikan Karakter}

Narwanti (2011: 14) menjelaskan pendidikan karakter adalah suatu sistem penanaman nilai-nilai karakter kepada kemauan, dan tindakan untuk melaksanakan nilai-nilai tersebut. Sipos (2010: 1) menjelaskan tentang pendidikan karakter sebagai berikut:

"Character education is the intentional effort to develop in young people core ethical and performance values that are widely affirmed across all cultures. To be effective, character education must include all stakeholders in a school community and must permeate school climate and curriculum."

Menurut Sipos, pendidikan karakter telah dijelaskan sebagai upaya yang disengaja untuk mengembangkan pada orang muda inti nilai-nilai etika dan kinerja yang banyak ditegaskan di semua budaya. Agar efektif, pendidikan karakter harus mencakup semua pemangku kepentingan dalam komunitas sekolah dan harus meresap iklim dan kurikulum sekolah.

Menurut Saptono (2011: 23) pendidikan karakter adalah upaya yang dilakukan dengan sengaja untuk mengembangkan karakter yang baik (good character) berlandaskan kebaikan-kebaikan inti (core virtues) yang secara objektif baik bagi individu maupun masyarakat. Penjelasan pendidikan karakter yang dirilis oleh Kementrian Pendidikan Amerika Serikat pada tahun 2007 adalah sebagai berikut:

"Character education is an in-clusive term embracing all aspects of how schools, related social institutions and parents can support the positive character development of children and adults. The term character includes the emotional, intellectual and moral qualities of a person or group as well as the demonstration of these qualities in prosocial behavior."

Pendidikan karakter yang dijelaskan dari pihak Kementrian Pendidikan Amerika Serikat adalah istilah insklusif yang merangkul semua aspek bagaimana sekolah, lembaga-lembaga sosial terkait, dan orang tua dapat mendukung pengembangan karakter positif anak-anak dan orang dewasa. Materi karakter meliputi kualitas emosional, intelektual, dan moral dari seseorang atau sekelompok seperti demonstrasi dari kualitas-kualitasnya dalam perilaku prososial.

Penulis berpendapat bahwa pendidikan karakter melingkupi tidak hanya lingkungan sekolah saja. Ruang lingkup pendidikan karakter selain di sekolah adalah di keluarga, masyarakat, instansi pemerintah maupun swasta, serta ruang lingkup di luar negeri. Oleh karena itu, pendidikan karakter merupakan tanggung jawab suatu bangsa pula.

\section{Penilaian Karakter}

Kementrian Pendidikan Nasional pada tahun 2010 telah merilis tentang nilai-nilai Pendidikan Budaya dan Karakter Bangsa. Ada 18 nilai karakter yang harus ditanamkan dalam pendidikan di sekolah dasar. Nilai-nilai karakter itu adalah religius, jujur, toleransi, disiplin, kerja keras, kreatif, mandiri, demokratis, rasa ingin tahu, semangat kebangsaan, cinta tanah air, menghargai prestasi, bersahabat/komunikatif, cinta damai, gemar membaca, peduli lingkungan, peduli sosial, dan tanggung jawab.

Untuk mengetahui nilai-nilai karakter maka dilakukanlah penilaian karakter. Penilaian merupakan serangkaian kegiatan yang sistematis dan berkesinambungan untuk memeroleh data dan informasi tentang proses dan hasil belajar peserta didik (Muhammad, 2015: 1). Penilaian karakter dapat dilakukan dengan penilaian sikap di sekolah dasar 
dilakukan oleh guru kelas, guru muatan pelajaran agama, PJOK, dan pembina ekstrakurikuler. Teknik penilaian karakter yang digunakan meliputi: observasi, wawancara, catatan anekdot (anecdotal record), dan catatan kejadian tertentu (incidental record) sebagai unsur penilaian utama.

Dalam penilaian sikap, diasumsikan setiap peserta didik memiliki karakter dan perilaku yang baik, sehingga jika tidak dijumpai perilaku yang menonjol maka nilai sikap peserta didik tersebut adalah baik, dan sesuai dengan indikator yang diharapkan. Perilaku menonjol (sangat baik/kurang baik) yang dijumpai selama proses pembelajaran dimasukkan ke dalam catatan pendidik. Selanjutnya, untuk menambah informasi, guru kelas mengumpulkan data dari hasil penilaian sikap yang dilakukan oleh guru muatan pelajaran lainnya, kemudian merangkum menjadi deskripsi (bukan angka atau skala).

Penilaian karakter dilakukan secara terus menerus dan dilakukan setiap saat guru berada di kelas atau di sekolah. Model anecdotal record atau catatan anecdotal (catatan yang dibuat guru ketika melihat adanya perilaku yang berkenaan dengan nilai yang dikembangkan) selalu dapat digunakan guru. Selain itu, guru dapat pula memberikan tugas yang berisikan suatu persoalan atau kejadian yang memberikan kesempatan kepada peserta didik untuk menunjukkan nilai yang dimilikinya. Dari hasil pengamatan, catatan anekdotal, tugas, laporan, dan sebagainya, guru dapat memberikan kesimpulan atau pertimbangan tentang pencapaian suatu indikator atau bahkan suatu nilai. Kesimpulan atau pertimbangan itu dapatdinyatakan dalam pernyataan kualitatif

Penanaman nilai karakter dapat dilakukan dalam kegiatan pembelajaran. Kegiatan pembelajaran dilaksanakan agar siswa sekolah dasar mempraktikan nilai-nilai karakter yang ditargetkan teraktualkan melalui kegiatan pendahuluan, kegiatan inti dan kegiatan penutup. Pada kegiatan pendahuluan, penanaman nilai karakter dapat dilakukan melalui contoh sebagai berikut:

1. Guru datang tepat waktu (nilai yang ditanamkan: disiplin).

2. Guru mengucapkan salam dengan ramah kepada siswa ketika memasuki ruangan kelas (nilai yang ditanamkan: santun, peduli).

3. Guru berdoa sebelum membuka pelajaran, dan siswa belajar memimpinnya (nilai yang ditanamkan: religius, partisipatif).

4. Guru mengecek kehadiran siswa (nilai yang ditanamkan: disiplin).

5. Guru mendoakan siswa yang tidak hadir atau karena halangan lainnya (nilai yang ditanamkan: religius, peduli).

6. Guru menegur siswa yang terlambat dengan sopan (nilai yang ditanamkan: disiplin, santun, peduli).

7. Guru meminta siswa menghapus papan tulis (nilai yang ditanamkan: peduli, bersih).

8. Guru mengaitkan materi yang akan diajarkan dengan karakter.

9. Guru menyampaikan butir-butir nilai yang akan dicapai dalam pembelajaran.

Pada kegiatan inti, penanaman nilai karakter dapat dilakukan melalui kegiatan eksplorasi, elaborasi, dan konfirmasi. Contoh penanaman nilai karakter yang dilakukan pada kegiatan eksplorasi adalah sebagai berikut:

1. Guru melibatkan peserta didik mencari informasi dari tema yang dipelajari berdasarkan aneka sumber belajar (menanamkan: kemandirian, berfikir logis, kreatif dan kerjasama). 
2. Guru menggunakan beragam pendekatan pembelajaran yang menantang dan memotivasi (menanamkan: kreatif, kerja keras).

3. Guru memfasilitasi interaksi antar peserta didik serta antara peserta didik dengah guru, lingkungan dan sumber belajar lainnya (menanamkan: saling menghargai dan peduli lingkungan).

4. Guru melibatkan peserta didik secara aktif dalam setiap kegiatan pembelajaran (menanamkan: percaya diri, mandiri).

5. Guru memfasilitasi peserta didik melakukan percobaan (menanamkan: mandiri, kerja keras, teliti).

Kegiatan inti yang kedua adalah kegiatan elaborasi. Contoh penanaman nilai karakter yang dilakukan pada kegiatan elaborasi adalah sebagai berikut:

1. Guru membiasakan membaca dan menulis melalui tugas tertentu (menanamkan: tekun, kreatif, gemar membaca).

2. Guru memfasilitasi diskusi kelas (menanamkan: kreatif, analitis, kritis, saling menghargai, santun).

3. Guru memfasilitasi pembelajaran kooperatif dan kolaboratif (menanamkan: kerjasama, saling menghargai, tanggungjawab).

4. Guru memfasilitasi kompetisi antar warga kelas secara sehat (menanamkan: jujur, menerima keputusan, kerja keras).

5. Guru memfasilitasi pembuatan laporan hasil eksplorasi/kerja secara individual maupun kelompok (menanamkan: mandiri, kerjasama, tanggungjawab, menghargai).
6. Guru memfasilitasi peserta didik menampilkan karya (menanamkan: percaya diri, menghargai karya, jujur, kerjasama).

Kegiatan inti yang ketiga adalah kegiatan konfirmasi. Contoh penanaman nilai karakter yang dilakukan pada kegiatan konfirmasi adalah sebagai berikut:

1. Guru memberikan umpan balik positif (menanamkan: percaya diri, saling menghargai, santun).

2. Guru memfasilitasi peserta didik melakukan refleksi terhadap pengalaman belajar yang telah dilakukan (menanamkan: menerima keadaan, syukur).

3. Guru memfasilitasi peserta didik menggali pengalaman dan pengetahuan lebih jauh (menanamkan: rasa ingin tahu, tidak cepat puas).

Kegiatan terakhir dalam kegiatan pembelajaran adalah kegiatan penutup. Contoh penanaman nilai karakter yang dilakukan pada kegiatan penutup adalah sebagai berikut:

1. Guru beserta peserta didik membuat rangkuman atau kesimpulan (menanamkan: kritis, logis, kerjasama).

2. Guru melakukan penilaian terhadap kegiatan yang sudah dilaksanakan (menanamkan: jujur, sukur, menerima kelebihan dan kekurangan).

3. Guru memberikan umpan balik terhadap proses dan hasil pembelajaran (menanamkan: saling menghargai, percaya diri, santun, kritis).

4. Guru merencanakan tindak lanjut baik remedi atau pengayaan (menanamkan: tanggung jawab).

5. Guru memfasilitasi siswa untuk berdoa dan berterima kasih (menanamkan: religiousitas, hormat pada guru). 


\section{Pengembangan Karakter}

Strategi pengembangan nilai karakter sesuai dengan strategi Samani dan Haryanto (2011: 144), yakni pemanduan, pujian dan hadiah, definisikan dan latihkan, penegakan disiplin, serta penghargaan setiap bulan. Pihak sekolah dasar dapat menggunakan strategi ini jika mereka ingin mengembangkan nilainilai karakter. Peran guru sangat penting dalam menjalankan strategi ini.

Pada tataran sekolah, kriteria pencapaian pendidikan karakter adalah terbentuknya budaya sekolah yaitu perilaku, tradisi, kebiasaan keseharian, dan simbol-simbol yang dipraktikkan oleh semua warga sekolah, dan masyarakat sekitar sekolah harus berlandaskan nilai-nilai tersebut (Asmani, 2012: 5556). Pengembangan karakter dapat dilakukan dimana saja. Pengembangan karakter dapat dilakukan dengan membuat slogan yang mampu menumbuhkan kebiasaan dalam segala tingkah laku masyarakat.

Pernyataan Peterson dan Deal (Zuchdi, 2011: 148), bahwa kepala sekolah, tim pengawal budaya sekolah dan karakter, guru, karyawan, siswa, dan orang tua/wali siswa mempunyai peran tersendiri dalam pengembangan nilai-nilai karakter. Pemantauan secara kontinyu merupakan wujud dari pelaksanaan pengembangan pembangunan yang berkarakter. Penilaian orang tua memiliki peranan yang besar dalam membangun pengembangan karakter anak.

Menurut Nurul (2007: 19) bahwa nilai-nilai adalah pengembangan pribadi siswa tentang pola keyakinan yang terdapat dalam sistem keyakinan suatu masyarakat tentang hal baik yang harus di lakukan dan hal buruk yang harus di hindari. Sedangkan seseorang dikatakan berkarakter atau berwatak apabila telah berhasil menyerap nilai keyakinan yang di kehendaki masyarakat serta di gunakan sebagai kekuatan moral dalam hidupnya. Lickona (1993) berpendapat tentang pengembangan karakter anak yaitu dengan komponen sebagai berikut:

1. Knowing the good (mengetahui yang baik)

2. Desiring the good (menginginkan yang baik)

3. Exampling the good (mencontohkan yang baik)

4. Loving good (menyukai yang baik)

5. Acting the good (melakukan yang baik)

Pengembangan karakter sesuai konsep dari Thomas Lickona juga dapat dilakukan dengan memasukkan konsep karakter pada setiap pembelajaran di sekolah dasar. Hal tersebut dilakukan dengan tujuan yaitu:

1. Guru menanamkan nilai kebaikan pada anak (knowing the good) menanamkan konsep diri kepada anak setiap akan memasuki pelajaran.

2. Guru menggunakan cara yang membuat anak memiliki alasan atau keinginan untuk berbuat baik (desiring the good).

3. Guru memberikan beberapa contoh baik kepada anak mengenai karakter yang sedang dibangun (exampling the good). Misalnya melalui cerita dengan tokoh-tokoh yang mudah dipahami siswa.

4. Guru mengembangkan sikap mencintai perbuatan baik (loving the good). Pemberian penghargaan kepada anak yang membiasakan melakukan kebaikan anak yang melanggar diberi hukuman yang mendidik.

5. Guru melaksanakan perbuatan baik (acting the good). Pengaplikasian karakter dalam proses pembelajaran selama disekolah.

Menurut Saptono (2011: 199) terdapat 19 cara yang digunakan dalam pengembangan karakter siswa sekolah. Beberapa cara tersebut dapat digunakan 
untuk mengembangkan pendidikan karakter di sekolah dasar, yaitu :

1. Memajang gambar-gambar para tokoh inspiratif di aula sekolah dan ruang-ruang kelas.

2. Membuat program penghargaan untuk mengapresiasi berbagai hal yang membanggakan, selain prestasi akademis, olahraga atau kesenian.

3. .Membuat pedoman perilaku di kelas dan sekolah yang disetujui oleh para siswa dan guru.

4. Mengundang para orangtua siswa untuk mengamati dan berkontribusi terhadap kemajuan kelas atau sekolah.

5. Meminta siswa mengungkapkan tokoh idola yang bersifat personal dan tanyakan mengapa tokoh itu menjadi idola siswa yang bersangkutan.

6. Memimpin para siswa dengan keteladanan.

7. Jangan biarkan berbagai bentuk ketidaksopanan terjadi di kelas.

8. Melibatkan orangtua siswa dalam mengatasi perilaku tidak baik siswa dengan cara mengirimkan surat, memanggil orangtua atau melalui kunjungan ke rumah yang bersangkutan.

9. Memastikan bahwa siswa memiliki tanggung jawab moral untuk bekerja keras di sekolah.

10. Memiliki kata-kata di dinding yang mendorong karakter yang baik, misalnya "Jangan tunggu untuk menjadi orang yang hebat, mulailah sekarang juga !".

11. Berusaha konsisten dalam memperlakukan siswa, jangan biarkan perasaan pribadi menghalangi seorang guru untuk bertindak adil.

12. Mengakui kesalahan dan berusaha untuk memperbaikinya.
13. Mengajarkan siswa mengenai kompetisi serta bantu siswa untuk mengerti kapan hal tersebut berguna dan kapan hal tersebut tak berguna.

14. Mengajarkan kesantunan secara jelas. Ajarkan kepada siswa begaimana mendengarkan orang lain dengan penuh perhatian dan tidak memotong pembicaraan orang lain.

15. Melakukan kerja bakti bersama baik di kelas atau sekolah.

16. Menunjukkan penghargaan terhadap siapapun yang berbeda keyakinan dan berbeda budaya. Katakan kepada siswa mengenai kewajiban moral untuk bertindak adil terhadap orang lain.

17. Tekankan kepada siswa tentang pentingnya kepedulian terhadap orang lain dan lingkungan.

18. Beri perhatian program-program tertentu di sekolah yang sarat muatan karakter, misalnya 'bulan penghargaan tokoh karakter'.

19. Menekankan pentingnya sikap ksatria (tidak curang) dalam berolahraga, bermain, dan dalam berbagai bentuk interaksi dengan orang lain.

Menurut Sipos (2010) terdapat 11 prinsip yang harus dicapai untuk mengembangkan pendidikan karakter yang efektif. Prinsip-prinsip ini apabila diterapkan di sekolah dasar akan menumbuhkan, membangun, dan mengembangkan karakter siswa sekolah dasar menjadi lebih baik. Kesebelas prinsip itu adalah sebagai berikut:

1. Komunitas sekolah mempromosikan nilai-nilai etika dan kinerja inti sebagai dasar karakter yang baik.

2. Pihak sekolah mendefinisikan "karakter" secara komprehensif mencakup pikiran, perasaan, dan tindakan. 
3. Pihak sekolah menggunakan pendekatan yang komprehensif, disengaja, dan proaktif untuk pengembangan karakter.

4. Pihak sekolah menciptakan komunitas yang peduli karakter.

5. Pihak sekolah memberikan siswa dengan kesempatan untuk melakukan tindakan moral.

6. Pihak sekolah menawarkan kurikulum akademik yang bermakna dan menantang yang menghormati semua peserta didik, mengembangkan karakter mereka, dan membantu mereka untuk berhasil.

7. Pihak sekolah menumbuhkan motivasi diri siswa.

8. Staf sekolah adalah komunitas belajar etis yang berbagi tanggung jawab untuk pendidikan karakter dan mematuhi nilai-nilai inti yang sama yang membimbing siswa.

9. Pihak sekolah menumbuhkan kepemimpinan bersama dan dukungan jangka panjang dari inisiatif pendidikan karakter.

10.Pihak sekolah melibatkan keluarga dan anggota masyarakat sebagai mitra dalam upaya pembangunan karakter.

11. Pihak sekolah secara teratur menilai budaya dan iklim, fungsi staf sebagai pendidik karakter, dan sejauh mana siswa memanifestasikan karakter yang baik.

\section{SIMPULAN}

Indikator dalam pendidikan diperlukan oleh pendidik demi pengembangan karakter siswa sekolah dasar. Pendidikan dan penilaian karakter yang diadakan di sekolah dasar digunakan untuk pengembangan karakter. Pengembangan karakter dilakukan untuk mengembangkan karakter siswa sekolah dasar sesuai karakter yang baik.
Ruang lingkup pendidikan karakter selain di sekolah adalah di keluarga, masyarakat, instansi pemerintah maupun swasta, serta ruang lingkup di luar negeri. Penanaman nilai karakter dapat dilakukan dalam kegiatan pembelajaran. Teknik penilaian karakter yang digunakan di sekolah dasar meliputi: observasi, wawancara, catatan anekdot, dan catatan kejadian tertentu.

Pengembangan karakter dapat dilakukan dengan memasukkan konsep karakter pada setiap pembelajaran di sekolah dasar. Beberapa pengembangan itu antara lain:

1. Guru menanamkan nilai kebaikan pada anak dengan menanamkan konsep diri yang baik kepada anak setiap akan memasuki pelajaran.

2. Guru menggunakan cara yang membuat anak memiliki alasan atau keinginan untuk berbuat baik.

3. Guru memberikan beberapa contoh baik kepada anak mengenai karakter yang sedang dibangun.

4. Guru mengembangkan sikap mencintai perbuatan baik.

5. Guru melaksanakan perbuatan baik. 


\section{DAFTAR PUSTAKA}

Asmani, J. 2012. Buku Panduan Internalisasi Pendidikan Karakter di Sekolah. Yogyakarta: Diva Press.

Effendi, M. 2016. Masalah Pendidikan Dasar, Ini Pendapat Mendikbud. http:/ banjarmasin.tribunnews.com/2016/08/22/ masalah-pendidikan-dasar-ini-pendapatmendikbud.

Kemendiknas. 2010. Desain Induk Pendidikan Karakter. Jakarta: Kementrian Pendidikan Nasional.

Kementrian Pendidikan Amerika Serikat. 2007. Mobilizing for Evidence-Based Character Education. USA: Washington.

Lickona, T. 1993. The Return of Character Education. http://www.ascd.org/publications/ educational-leadership/nov93/vol51/num03/TheReturn-of-Character-Education.aspx.

Muhammad, H. 2015. Panduan Penilaian untuk Sekolah Dasar. Jakarta: Kementrian Pendidikan dan Kebudayaan.

Nurul, Z. 2011. Pendidikan Moral dan Budi Pekerti Dalam Perspektif Perubahan. Jakarta: Bumi Askara.

Pasaribu, A. 2016. Komisi X DPR Prihatin Banyak Siswa Putus Sekolah. http:/ www.antaranews.com/berita/590067/komisi-Xdpr-prihatin-banyak-siswa-putus-sekolah.

Saptono. 2011. Dimensi - dimensi Pendidikan Karakter. Jakarta: Esensi Erlangga grup.
Narwanti, S. 2011. Pendidikan Karakter. Yogyakarta :Familia.

Samani dan Hariyanto. (2012). Konsep dan Model Pendidikan Karakter. Bandung: PT Remaja Rosda Karya.

Sipos, R. 2010. Eleven Principles of Effective Character Education. http:// www. character.org/elevenprinciples.

Sudiaman, M. 2014. Inilah Kronologi Kasus Bully Anak SD di Bukittinggi. http:// www.republika.co.id/berita/nasional/daerah/14/ 10/12/ndbsmg-inilah-kronologi-kasus-bully-anaksd-di-bukittinggi.

Suhartadi, I. 2016. Tiga Puluh Enam Murid SD Mengikuti Konferensi Anak Indonesia. http:// www.beritasatu.com/pendidikan/398018-36murid-sd-ikuti-konferensi-anak-indonesia2016.html.

Taufik, M. 2016. Di Gresik Banyak Sekolah Kekurangan Siswa, begini Solusi Dinas Pendidikan. http://surabaya.tribunnews.com/ 2016/08/31/di-gresik-banyak-sekolahkekurangan-siswa-begini-solusi-dinas-pendidikan.

Zuchdi, D. 2011. Pendidikan Karakter dalam Prespektif Teori dan Praktik. Yogyakarta: UNY Press. 